\title{
Um crescendo de tomada de consciência: a Conjuração Baiana de 1798 no primeiro centenário da Independência do Brasil
}

\author{
A growing awareness: the Bahia Conjuration of 1798 in the first centenary of the \\ Independence of Brazil
}

\author{
Patrícia Valim \\ Doutora em História \\ Professora do PPGH-UFBA \\ patricia.valim@ufba.br
}

\begin{abstract}
Resumo: $\mathrm{O}$ artigo analisa o modo pelo qual a historiografia ligada ao Instituto Geográfico e Histórico da Bahia, no período do primeiro centenário da Independência do Brasil, inverteu o polo das análises oitocentistas sobre a Conjuração Bahiana de 1798 -um evento pedagógico da história pátria em razão da criminalização do exercício político de homens livres, pobres e adeptos ao projeto de nação repuplicana -, para considerá-lo como a etapa popular do processo de tomada de consciência da situação colonial que resultou na Independência do Brasil, em 1822.
\end{abstract}

Palavras-chave: Historiografia, Conjuração Baiana de 1798, Independência do Brasil.

\begin{abstract}
The article analyzes the way in which the historiography linked to the Geographical and Historical Institute of Bahia, in the period of the first centenary of the Independence of Brazil, inverted the pole of the 19th century analyzes of the Conjuration of Bahia in 1798 - a pedagogical event in the country's history due to the criminalization of the political exercise of free, poor and adept men to the repuplican nation project -, to consider it as the popular stage of the process of becoming aware of the colonial situation that resulted in the Independence of Brazil, in 1822.

Keywords: Historiography, Bahia Conjuration of 1798, Independence of Brazil.
\end{abstract}


Em 2002, no decorrer da campanha que elegeria Lula à presidência do Brasil, os alunos do ensino médio da modalidade suplência, em uma escola do ABC Paulista, foram contaminados pela esperança. Aguardavam ansiosos pelo dia em que um de seus pares, um ex sindicalista, assumiria o mais alto posto da burocracia estatal, a Presidência da República Federativa do Brasil. A possibilidade inédita de um governo popular, que efetivamente os representasse nas estruturas internas do Estado, fez da escola um dos espaços privilegiados para que os alunos-trabalhadores refletissem sobre a historicidade da sua participação política. Sociedade essa que, em seus termos, até aquele momento insistia em excluí-los do universo da política. Foi nesse espraiar que o tema das revoltas coloniais no final do século XVIII foi abordado em sala de aula e suscitou manifestações de toda sorte.

Na ocasião, o livro didático sugerido pela coordenação do curso abordava o tema das referidas revoltas, vislumbrando-se a Independência como o fim do caminho. Assim, foi via 1822, que o livro encadeou a Inconfidência Mineira de 1789 e a Conjuração Baiana de 1798, carregando na tinta o processo de tomada de consciência para a ação política separatista (ARRUDA \& PILETTI, 2000). Para a conclusão do tema, o recurso adotado no livro foi um quadro adaptado da obra de Fernando Antônio Novais, Portugal e Brasil na crise do antigo sistema colonial (1777-1808), com a seguinte citação: “A Inconfidência Mineira e a Conjuração Baiana podem legitimamente considerar-se movimentos precursores da emancipação política do Brasil. Elas formam um crescendo de tomada de consciência que, pelo menos para o Nordeste, não se conteve com a vinda da corte e as mudanças que isso implicou" (ARRUDA \& PILETTI, 2000: 257).

Embora a abordagem buscasse as contradições e as similitudes dos eventos, tornando o episódio baiano tributário do mineiro, em uma temporalidade de longa duração (MOTA \& NOVAIS, 1998), foi a partir da distinta composição social que as revoltas adquiriram significação no livro didático. Assim, à exceção de Tiradentes, a Inconfidência Mineira aparece como um movimento político liderado por membros da elite mineira colonial e a Conjuração Baiana um movimento liderado por "pessoas simples, como mulatos, libertos e até mesmo escravos" (MOTA \& NOVAIS, 1998). Para a verificação da aprendizagem, o livro sugeriu uma atividade na qual os alunos escrevessem a respeito das semelhanças e diferenças dos movimentos de 1789 e 1798, relacionando-as com o trecho da obra de Carlos Guilherme Mota: "O conceito de 
independência surge mais nítido nas Minas Gerais: a situação colonial pesa para esses homens proprietários; o problema é mais colonial que social. [...] na Bahia de 1798, a inquietação é orientada por elementos da baixa esfera e a revolução é pensada contra a opulência [...]" (MOTA, 1986: 115 apud ARRUDA \& PILLETI, 2000).

No exemplar do professor do livro didático, no item com as respostas das atividades propostas, duas questões eram fundamentais para uma resposta correta em relação ao tema: a dicotomia da composição social dos episódios - Mineira/elite X Baiana/popular - e a relação dos movimentos com a Independência do Brasil. As respostas das atividades seguiram o padrão desejado e estabelecido pelo livro didático, contudo um aluno apresentou o tema da seguinte forma:

[...] a Bahia [Conjuração Baiana de 1798] foi um exemplo de luta dos companheiros por melhores condições de trabalho, salários justos e por oportunidades de participação naquele governo. Infelizmente eles [partícipes] não tiveram uma liderança capaz chefiar o movimento e brigar contra os poderosos, por isso foram enforcados. [...] Não sei se eles queriam uma Revolução, acho mesmo que nem saberiam fazer naquele momento. Foi preciso muito tempo para que o povo aprendesse que é chegada a nossa hora, o tempo de vingarmos os destinos daqueles pobres coitados. [...] não lutamos pelos privilégios da burguesia como os mineiros [Inconfidência Mineira de 1789], mais (sic) por dignidade, por um lugar na sociedade, por trabalho, comida e casa, assim como aqueles baianos (TRECHO de redação elaborada por um aluno do $2^{\circ}$ ano do Ensino Médio da modalidade de Educação de Jovens e Adultos, no $2^{\circ}$ semestre de 2002).

Como se pode notar, a redação do aluno substituiu a Independência do Brasil por outro evento dotado de ruptura para ele: a eleição de um líder sindicalista à Presidência do Brasil. Cabe lembrar novamente que, nos idos de 2002, a vitória de um líder popular aparece no trecho como a efetivação da promessa de um governo representativo de fato e a participação da classe trabalhadora nas estruturas internas do Estado - projeto que o aluno reconhece como seu e dos baianos de 1798.

Há referência à precária condição de vida daqueles baianos e à ausência de possibilidade de participação naquela sociedade, mas, paradoxalmente, não é o limite político e social para os homens livres em uma sociedade escravocrata, imposto pelo Estado absolutista e pelo esquema interno de forças, articulado pela elite colonial, o 
principal ponto de significação do evento na redação do aluno. Ao contrário, o ponto de significação é a ausência de amadurecimento político dos baianos de 1798: a incapacidade de articulação política dos baianos, a falta de uma liderança popular e de projeto político consistente.

Não à toa, é na ausência de um líder que levasse a cabo as reivindicações dos baianos de 1798 que o aluno vê a razão do malogro do evento e do derivado enforcamento dos quatro homens pardos em praça pública, condenados por crime de lesa-majestade. Nessa perspectiva, a representação do evento aparece como a etapa inicial de um longo processo de amadurecimento político da classe popular que, como vimos, não representou o perigo que as autoridades da época vislumbraram, pois para o aluno, tanto na Bahia de 1798 como no Brasil de 2002, buscava-se um espaço naquela sociedade e não a subversão da sua ordem.

Cumpre destacar que a redação do aluno estabeleceu uma relação extremamente fecunda a partir da cultura histórica do livro didático que possibilitou a confluência temporal de projetos políticos no processo de atualização da Conjuração Baiana de 1798 como a antessala de um outro evento histórico dotado de ruptura: a independência política do Brasil e/ou a eleição de um líder sindical à presidência do país (uma outra independência para um aluno trabalhador).

Considerando que a Independência política do Brasil é um evento histórico presente em todos os livros didáticos de História do Brasil, para os Ensino Fundamental e Médio, o segundo recurso de divulgação de conteúdo histórico mais lido no país, importa destacar para o objetivo deste artigo as bases historiográficas da Conjuração Baiana de 1798 que compõem essa memória histórica sobre a Independência Política do Brasil veiculada no livro didático e que adquiriu um sentido mais amplo na redação do aluno trabalhador.

A hipótese é que após a Proclamação da República, a historiografia ligada ao Instituto Geográfico e Histórico da Bahia inverteu o polo das análises oitocentistas sobre a Conjuração Bahia de 1798 como um evento de caráter pedagógico ao integrar a narrativa pátria a partir da criminalização do exercício político de homens livres, pobres, pardos e afinados com os princípios republicanos de nação para considerá-lo como a etapa popular de 1822. Essa operação historiográfica acabou invertendo a posição periférica desses historiadores regionais para ocuparem lugar de destaque na História do Brasil dali para frente e assim por diante. 
Em 1860, o cônego Joaquim Caetano Fernandes Pinheiro publicou na sessão “contos e narrativas", da Revista Popular, o artigo intitulado "A Conjuração de João de

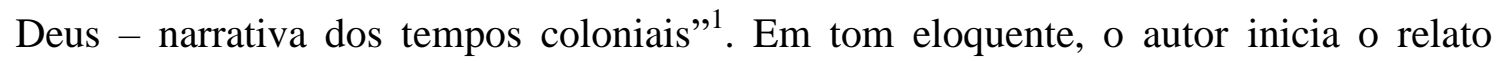
afirmando que:

gravado ainda estava na memória de todos o triste desfecho da tentativa republicana em Minas, parecia ainda ouvir-se as últimas palavras do Tira Dentes ou magoados queixumes do amante de Marília, e já na antiga capital do Brazil erguia-se de novo o cadafalso de quatro infelizes hallucinados expiavão ahi seus sonhos de liberdade e independência (BN, Revista Popular, tomo VIII, 1860: 218).

Joaquim Caetano afirma que durante o governo de d. Fernando José de Portugal e Castro "apesar do cuidado com que hermeticamente fechados tinham os nossos portos [aportaram] a esses climas os princípios que em seu triumpho derrubarão o throno de $\mathrm{S}$. Luiz, ateando por toda a Europa assombroso incêndio”. Segundo o cônego,

audaciosamente procurados erão os corypheus ensyclopedicos, e com o atractivo do fructo prohibido saboreadas as suas máximas. Podia-se com verdade dizer que, salvas raras excepções, sympathizavão os Brazileiros com as nossas idéias, com tanto enthusiasmo por isso que se sentião opprimidos, e com secreto pressentimento antevião os arreboes de sua emancipação (BN, Revista Popular, tomo VIII, 1860: 218).

Após essa breve introdução acerca da situação da cidade de Salvador, na qual a Independência do Brasil passa a ser "pressentida" pelos brasileiros "oprimidos", Joaquim Caetano relata que, no dia 27 de agosto de 1798, compareceram perante o desembargador Francisco Sabino Alves da Costa Pinto, Joaquim José da Veiga, Joaquim José de Sant'Anna e José Joaquim de Siqueira, denunciando como conspiradores a João de Deus, alfaiate, e Lucas Dantas, soldado do regimento da artilharia. A seu ver,

nem o caracter e posição social dos denunciados, nem a natureza dos planos, que lhes erão attribuidos, podião discutir o receio pela tranqüilidade publica.

1 Cf. Biblioteca Nacional, doravante BN, sessão de obras raras, PR-SOR-03143[1-8]. 
Suspeita inquieta porém andava a auctoridade, e tanto bastava para que rodeando-se do aparato da lei, desse importância ao que de si não tinha. A má interpretação das idéias dominantes na revolução franceza, originada pela ignorância dos chefes visíveis da conjuração, davão-lhe uma cor socialista, pouco própria para angariar-lhe as sympathias das classes mais illustradas e influentes da população (BN, Revista Popular, tomo VIII, 1860: 218).

Ao tratar de um dos eixos de maior controvérsia do evento de 1798, o cônego afirma que:

nem uma luz derramão os documentos que temos à vista sobre o verdadeiro chefe da mallograda empreza: na lista porem dos prezos deparamos com o nome do bacharel Cypriano José Barata de Almeida, cirurgião approvado. Ora, quem se recordar do importante papel, que no tempo do Sr. D. Pedro desempenhou esse fogoso tribuno, não deverá acreditar que d'elle partisse o pensamento, cuja execução confiara a indivíduos da plebe, porque n'ella principalmente procurava apoiar-se. Na lista dos trinta e seis prezos avulta o seu nome, e não sabemos como escapasse essa circumstancia ao juiz formador da culpa, para, deixando immune, ir descarregar a espada da justiça sobre a cabeça d'insignificantes comparças (BN, Revista Popular, tomo VIII, 1860: 218).

Embora não reconheça nesse ponto o verdadeiro chefe da revolta baiana de 1798, Joaquim Caetano menciona Cipriano Barata como um "fogoso tribuno", dada a virulência com a qual defendia suas ideias liberais, sugerindo que o cirurgião era, senão o mentor, um dos protagonistas do evento. Ao mesmo tempo, Joaquim Caetano afirma, com argúcia, que Cipriano Barata não poderia ser o chefe da revolta, cujo pensamento teria sido confiado à execução "por indivíduos da plebe" e presentes nos pasquins afixados em locais públicos da Salvador:

Annunciavão a egualdade e paternidade dos cidadãos, a abertura das portas aos navios estrangeiros; a estincção dos tributos e monopólios; a liberdade de todos os escravos; o aumento dos soldos das tropas, devendo cada soldado ganhar duzentos réis diários; a aptidão dos homens de cor aos mais altos postos da milícia; a supressão da clausura monacal, podendo os frades e 
as freiras que quizessem sahir de seus conventos (BN, Revista Popular, tomo VIII, 1860: 218).

De acordo com o cônego, "ao lado d'essas medidas, que poderião ser tachadas d'innocentes utopias, havião outras que revelavão os instinctos ferozes da plebe, e que tanto fazem-no tremer o seu domínio" e que afastavam a suspeita do protagonismo de Cipriano Barata. Assim, Joaquim Caetano alerta que:

falavão os conjurados no assassinato das principais auctoridades, exceptuando-se o governador, que por um singular delírio julgavão seu cumplice, pretendendo collocal-o à frente de sua chimerica republica. Não esquecião também a terrível ameaça do saque que como a espada de Democles está sempre suspensa sobre a cabeça dos ricos suspeitos de não partilharem dos princípios revolucionários (BN, Revista Popular, tomo VIII, 1860: 218).

Na tentativa de reafirmar a baixa composição social da revolta baiana de 1798, ao mesmo tempo em que associa as "inocentes utopias" às ideias de Cipriano Barata, Joaquim Caetano reabre a questão sobre o verdadeiro chefe do movimento, com uma indagação:

Dissemos que nem o caracter, nem a posição social dos pretendidos cabeças da revolta deverão inspirar ao governo a menor inquietação: e de facto, que preponderância poderião ter sob um povo tão illustrado, como por certo era o baihano, o pobre pardo alfaiate João de Deus, e os soldados Lucas Dantas Amorim e Luiz Gonzaga das Virgens, elevado às honras de secretario, e de cuja perícia grammatical ficarão exuberantes provas nos documentos a que acima alludimos? (BN, Revista Popular, tomo VIII, 1860: 218).

Depois de afirmar que "apezar da jactância com que em seus plebiscitos diziam serem 676 os filiados em sua apreciação, contando-se n'esse número pessoas de elevada posição, cremos piamente que não passavam elles do 36 [...]”, Joaquim Caetano toca numa questão praticamente inédita do movimento: João de Deus do Nascimento e Lucas Dantas aliciaram “grande número de escravos, engodados na esperança d'alforria, e sob este ponto de vista, cumpre confessar, que bem funestos poderião ser os resultados da planejada revolução". 
O excesso retórico de Joaquim Caetano, em relação ao número de escravos foram dez, segundo os Autos das Devassas, depois que um deles morreu no segredo da Relação $^{2}$-, é simbólico do grande medo que assolava os homens de letras durante boa parte do oitocentos: uma revolta escrava nos moldes da que ocorreu no Haiti, a partir de 1791 e a Guerra de Secessão americana, 1861 a 1865.

Joaquim Caetano passa a demonstrar o que ele denomina de "estultícia dos conjurados", valendo-se do depoimento do denunciante Joaquim José da Veiga, assim como Inácio Accioli o fez, para descrever “os pormenores d'um d'esses ajunctamentos", mencionando os partícipes do encontro malogrado no Campo do Dique do Desterro.

Dadas as Ave Marias deu elle denunciante, na forma ajustada para a porta do dicto João de Deus, onde achou já, além d'esse, os seguintes: José do Sacramento, soldado do quarto regimento, official d'alfaiate, que the parece assiste às Mercês; Luiz, pardo, escravo do secretario d'este estado José Pires de Carvalho e Albuquerque; Ignácio da Silva Pimentel, soldado do segundo regimento; um moleque apprendiz, que lhe parece escravo do tabellião Bernardino de Senna e Araújo [...] e chegando ao Dique não acharão pessoa alguma, do que admirado o dicto João de Deus disse para elle denunciante e para os outros: - Não sei como isto é! Pois Antonio José, $1^{\circ}$. boleeiro de Caetano Mauricio, e Lucas Dantas, tinhão ficado de vir e de trazerem ambos consigo sessenta homens - e logo se resolverão a passar ao botequim, que fica por detraz do muro das freiras do Desterro, que é d'um pardo chamado Manoel Anselmo, e ahi se mandou vir um copo de aguardente [...] (BN, Revista Popular, tomo VIII, 1860: 218).

A partir da citação, até então inédita, dos nomes dos cativos e dos cargos ocupados por seus proprietários, o cônego demonstrará a tensão social gerada quando, no oitocentos, se avizinhava qualquer possibilidade de participação política dos setores populares. Para Joaquim Caetano o mundo dividido entre os que governam, a classe senhorial, e os que trabalham, os escravos, poderia ter o tecido social corrompido pelo mundo da desordem, constituído basicamente pelos diferentes tipos de homens livres e pobres, que à época do segundo Reinado faziam muito barulho com suas revoltas. 
Um mundo de fronteiras porosas, no qual homens como João de Deus aparecem na análise, de acordo com o diálogo depreciativo, corrompendo os dois mundos anteriores. Levando-se em conta que os diálogos da narrativa de Joaquim Caetano não encontram paralelo na documentação, o objetivo do cônego foi o de desqualificar as ações políticas do vulgo, homens como João de Deus do Nascimento. Assim, para Joaquim Caetano a revolta baiana de 1798 não passou de "conciliábulos, compostos das fezes da população bahiana, sem bases determinadas, reunidos em um lugar público e terminando em um botequim!”3. Em relação à ação política do vulgo, Joaquim Caetano passa a identificar o chefe da revolta, afirmando categoricamente que "do caracter irresoluto do ostensivo chefe João de Deus, fornece-nos provas outro trecho do depoimento supra citado [...]" (BN, Revista Popular, tomo VIII, 1860: 221).

A descrição do caráter do chefe da revolta baiana de 1798 não é um recurso de pouca relevância, uma vez que o cônego caminha entre a falta de caráter do vulgo como possibilidade de corromper a ordenação do corpo coletivo, a sociedade, e o respectivo controle no seu justo termo e limite. Os populares, faltos de caráter por natureza, se perderiam no exercício da política, universo por excelência da classe senhorial. Tanto mais que, no desfecho da narrativa, o cônego retoma o que até então tinha ficado em aberto, sugerindo, pela primeira vez, uma maior composição social do evento, a partir do questionamento da punição das autoridades coloniais aos réus enforcados em praça pública.

Se, como conhece o Sr. Varnhagen, a revolução da Bahia não tinha chefe, ou pelo menos não queria elle manifestar-se, deixando-se até nas mãos da ignorância a redacção dos documentos officiaes, não vemos a necessidade das medidas de extremo rigor à que recorreu o governo portuguez, confirmando a sentença proferida pela relação, que condennava à morte a João de Deus do Nascimento, cabo d'esquadra de milícias, os dous soldados Lucas Dantas e Luiz Gonzaga das Virgens, e o criolo liberto Manoel Faustino, que apenas contava com 18 annos de edade! (BN, Revista Popular, tomo VIII, 1860: 221).

\footnotetext{
${ }^{3}$ Chamamos atenção para o fato de que durante o ano de 1850 , os principais motivos para a prisão de homens livres e pobres e escravos foram a desordem e a embriaguez, respectivamente. Cf. GRINBERG, Keila. O fiador dos brasileiros: cidadania, escravidão e direito civil no tempo de Antônio Pereira Rebouças. Rio de Janeiro: Civilização Brasileira, 2002.
} 
Entrevendo que os condenados à morte, dado o caráter de João de Deus do Nascimento, foram a linha de frente para o verdadeiro chefe, muito provavelmente Cipriano Barata, Joaquim Caetano, ao demonstrar anteriormente que as "quiméricas utopias" poderiam suscitar no vulgo ações criminais de toda sorte, questiona os termos das punições das autoridades dos tempos coloniais, pois, a seu ver:

a prisão, e talvez o desterro dos mais influentes e os castigos corporaes applicados aos escravos, serião mais que sufficientes para abafar a idéia da revolta, mallogrando uma conjuração que deveu toda a sua importancia aos terrores que soube inspirar aos que nessa epocha governavão o nosso paiz. Pensavam porém os magistrados e políticos d'esse tempo que era necessário ostentar um grande apparato de força sempre que apparecia o menor simptoma de rebellião (BN, Revista Popular, tomo VIII, 1860: 221).

O cônego retoma a retórica da revolução como direito de resistência, para demonstrar, a partir do ostensivo aparato da punição exemplar, a inflexibilidade dos magistrados e o despotismo das autoridades coloniais como causas da revolta baiana de 1798. Neste particular, além de demarcar as diferenças entre a "sagrada mansidão" da administração do segundo Reinado, da qual o autor fazia parte, e o despotismo da administração dos tempos coloniais, Joaquim Caetano reafirma o que ele cria ter sido a verdadeira causa do conflito:

Uma proveitosa licção se pode comtudo tirar d'essa burlesca farça, infelizmente terminada no cadafalso, e vem a ser que o descontentamento popular originado pelos erros dos governantes, fornecerá sempre o elemento vivaz de todas as revoluções, e que por maior cuidado que se tenha de submetter a severas quarentenas as idéias liberaes farão ellas, à similhança das epidemias que zombão dos lazaretos e cordões sanitários, a sua erupção tanto mais terrível quanto mais for o soffrimento imposto pelo despotismo (BN, Revista Popular, tomo VIII, 1860: 221).

Joaquim Caetano Fernandes Pinheiro altera o tom da crítica em relação às ideias liberais quando passa a considerar quais seriam as consequências políticas, se essas ideias tivessem base social. Assim, o autor encerra a narrativa sobre a revolta baiana de 1798 com um recado com endereço certo: 
Não descem as theorias metafysicas às camadas inferiores da população, não comprehendem os mappas as theses de direito publico, conhecem porém intuitivamente que padecem, aspirão por melhorar a sua sorte, e prestam attentos ouvidos às seducções de alguns ambiciosos, que sobre a sua credulidade firmão o pedestal do seu poder. Difficil, senão impossível, é sublevar um povo feliz, que vive sob o regime de sabias e justas leis: por conta pois dos maus governos deveremos lançar a responsabilidade de todas as perturbações da ordem social (BN, Revista Popular, tomo VIII, 1860: 221).

Como se viu, o artigo de Joaquim Caetano Fernandes Pinheiro não é um texto propriamente historiográfico, uma vez que o cônego intercala informações extraídas da documentação com diálogos ficcionais entre os partícipes da revolta. De acordo com Márcia Abreu, até a década de 60 do oitocentos, os romances históricos publicados nos vários periódicos da Corte eram vistos com certo descaso, porque a leitura não era restrita à elite letrada versada no romantismo europeu. Essa crença se alicerçava no fato de o romance de natureza histórica não requerer uma série de procedimentos característicos das práticas de leitura dos gêneros clássicos e historiográficos ${ }^{4}$. Tanto mais que suas publicações eram feitas nos periódicos de considerável circulação na época.

Todavia, se o romance era visto com reservas por alguns eruditos, parece inegável que esse tipo de publicação tem um aspecto pedagógico em relação ao público leitor caro aos beletristas que compunham simultaneamente os quadros do Instituto Histórico e Geográfico Brasileiro e da administração do segundo Reinado. É o próprio Joaquim Norberto de Sousa e Silva, já presidente da agremiação, quem esclarece a relevância política desse gênero histórico-literário e a razão pela qual alguns sócios efetivos da agremiação trataram de temas nacionais em romances históricos publicados, sobretudo, nas páginas da Revista Popular. Para Joaquim Norberto,

O romance é d'origem moderna; veio substituir as novellas e as histórias; que tanto deleitavam nossos paes. É uma leitura agradável, e diríamos quase um alimento de fácil digestão proporcionado a estômagos fracos. Por seu 
intermédio pode-se moralizar e instruir o povo fazendo-lhe chegar ao conhecimento de algumas verdades metaphysicas, que aliás escapariam a (sic) sua compreensão (1855: 17).

Como se viu, o artigo de Joaquim Caetano Fernandes Pinheiro se enquadra na perspectiva moralizadora e pedagógica dos romances históricos acerca de algumas "verdades" sobre os temas caros à história pátria, cuja interpretação encontrava-se à época longe de ser hegemônica entre os que compunham as fileiras intelectuais do segundo Reinado. $\mathrm{O}$ autor estabelece um diálogo crítico com a interpretação inaugural de Francisco Adolfo de Varnhagen, especialmente no que tange à ausência de base social e operacionalidade política das "quiméricas utopias" de homens como Cipriano Barata e, sobretudo, dos homens livres e pobres.

Se Varnhagen, ao descrever as proposições dos partícipes da revolta de 1798, veiculadas nos pasquins sediciosos, demonstrou a existência de bases teóricas para as ações dos revoltosos livres e pobres, Joaquim Caetano, ao contrário, inverteu essa lógica para demonstrar o perigo das ideias republicanas quando apropriadas por esse setor. Ao descrever que as bases teóricas de um Cipriano Barata não passavam de uma utopia "em quarentena", mas para o vulgo significava, antes de mais nada, a desordem social externalizada em assassinato das autoridades, saques e convulsões sociais de toda sorte, o cônego sugere, por meio de diálogos ficcionais, o instinto "selvagem" desses homens. Chega, inclusive, a afirmar que "não descem as teorias metafísicas às camadas inferiores da população", sugerindo que as ideias republicanas eram toleradas quando eram mobilizadas pela classe senhorial.

Neste ponto, em especial, Joaquim Caetano não condena os projetos políticos de inspiração republicana, mas o didatismo do artigo do cônego caminha na direção de alertar seus opositores para a ameaça de corrupção do tecido social, caso o vulgo efetivamente participasse do universo da política. Ao afirmar que João de Deus do Nascimento tinha "falta de energia e mesmo a habilidade que muitas vezes supre o talento e a instrução", Joaquim Caetano parece retomar Montesquieu em sua proposição de que as repúblicas fundamentam-se, sobretudo, na virtude, demarcando a clivagem entre os virtuosos do poder e os faltos de caráter. Daí a exploração melodramática da ausência de caráter do vulgo como impossibilidade de participação política, sem avançar no viés republicano da revolta de 1798 explicitado nos pasquins manuscritos e 
publicados integralmente na primeira edição de História Geral do Brasil de Francisco Adolfo de Varnhagen, em 1854, em Madrid.

O ano da publicação do artigo de Joaquim Caetano Fernandes Pinheiro era 1860, período no qual o Segundo Reinado já dava os primeiros sinais de desgaste e a campanha abolicionista ganhava cada vez mais as páginas dos periódicos da corte. Com a Lei Eusébio de Queirós, de 1850, que definitivamente decretou o fim do tráfico internacional de escravos, houve o acirramento do abolicionismo e um crescente debate sobre a substituição da mão de obra escrava pelo trabalhador livre. Nesse processo, o lugar a ser ocupado pelos escravos na sociedade foi questão relevante para os beletristas de todas as cores.

Quando Joaquim Caetano afirma a existência de "muitos" escravos na revolta de 1798, ficcionando mais uma vez o diálogo entre João de Deus do Nascimento com alguns cativos, chama a atenção para o perigo de uma ameaça socialmente legitimada se houvesse, de fato, uma aliança política entre os setores populares da revolta: escravos e homens livres e pobres. Ao demonstrar uma espécie de cooptação política dos cativos à revolta baiana de 1798, capitaneada por João de Deus, o cônego novamente reafirma sua posição diante dos clivados contornos sociais entre quem trabalhava e quem fazia política; entre quem mandava e quem obedecia, e quem ousou desviar sua trajetória original no decorrer do século XIX.

Tanto mais que Cipriano Barata é qualificado pelo cônego como alguém que teve relevante papel na Independência do Brasil, para, em seguida, ser considerado, se não o mentor da revolta de 1798, alguém que defendia as "quiméricas utopias", cuja implantação, dada sua ilustração, não destinaria a homens como João de Deus do Nascimento. Joaquim Caetano, neste particular, não só prima pela descontinuidade entre a administração do segundo Reinado, da qual ele ocupava importante cargo, como refuta a acusação de despotismo extemporâneo de Pedro II, ao demonstrar que despóticas eram as autoridades dos tempos coloniais que enforcaram e esquartejaram os quatro homens livres e pobres, quando lhes bastariam a punição de degredo e açoites em praça pública, uma vez que o estado natural de "selvageria" do vulgo não lhes permitiria teorizar a respeito da revolta.

Ao retomar a proposição da retórica da revolução como direito de resistência, tudo leva a crer que o principal termo do artigo de Joaquim Caetano, acerca da revolta baiana de 1798, é a redenção do "selvagem", do vulgo, pela mensagem civilizadora da administração de Pedro II. Essa imagem, presente com eloquência no romance histórico 
do autor, pertence a uma espécie de construção consensual da imagem modernizadora de Pedro II e da sua administração, para reforçar com tintas fortes as noções de pátria e nação que ainda não tinham encontrado lugar definitivo no imaginário da sociedade oitocentista $^{5}$. Joaquim Caetano soube aproveitar com argúcia esse dado quando afirmou que a principal causa para todas as rebeliões era a ausência de "justas e sábias leis" dos governos despóticos dos tempos coloniais encerrados com a Independência do Brasil por d. Pedro I, em 1822.

Não parece ser por outra razão que, nos termos do próprio Joaquim Caetano, a administração do segundo Reinado era caracterizada, sobretudo, por dois pilares de enorme apelo ideológico e resultantes das características pessoais do imperador: a sagrada mansidão e o progresso. A modernidade, nesse processo, portanto, foi pensada em oposição ao passado dos tempos coloniais e conferida à nação brasileira sob os auspícios de Pedro II, cujo império viveu o apogeu de sua grandeza e estabilidade.

O fato é que a análise de Joaquim Caetano Fernandes Pinheiro acerca da revolta baiana de 1798 demonstra que o processo de construção de uma história pátria hegemônica ocorreu não sem tensões e disputas entre as fileiras do mesmo grupo de intelectuais. A informação que beira a obviedade nos remete a outra menos evidente: ao destacar com desprezo o movimento político de contestar as autoridades coloniais no final do século XVIII, o autor criminaliza o exercício político dos homens livres e pobres ao tempo em que marca a posição de um projeto de nação republicana só poderia ser efetivado por homens instruídos e proprietários, os mesmos afinados com a política de gabinete bastante desgastada de d. Pedro II.

Esses eixos de significação do evento foram retomados nas análises sobre o significado Conjuração Baiana de 1798 por ocasião das comemorações do primeiro centenário da Independência do Brasil, em 1922:

coube aos historiadores republicanos, já liberados dos bloqueios mentais que, durante o anterior período monárquico e escravista recomendavam, sob o risco de colisão com os fundamentos do poder e do Estado, a desqualificação a priori de projetos políticos libertários em cujo interior

5 Esse processo de construção consensual da ideia de modernidade de Pedro II e sua administração durante o segundo Reinado é sugestivo da proposição de Pierre Bourdieu, para quem a concordância e a integração social segue os pressupostos de Durkheim, no qual os símbolos "tornam possível o consensus acerca do sentido do mundo social que contribui fundamentalmente para a reprodução da ordem social: a integração lógica é a condição da integração moral”. Cf. BOURDIEU, Pierre. O Poder simbólico. Rio de Janeiro: Bertrand Brasil, 1989: 9-11. 
confraternizavam com homens de condição social tão desigual como ocorreu na Bahia (JANCSÓ, 2001: 299).

Com a fundação do Instituto Geográfico e Histórico da Bahia, em 1894, os historiadores buscaram ressaltar as especificidades da história regional para afirmar a importância da então província da Bahia no processo de construção da história nacional $^{6}$. Assim, a historiografia regional nobilitou-se por consagrar novos mitos, representações simbólicas e um saber histórico destinado a demarcar o que deveria ser rememorado e a excluir o que precisava ser esquecido, muitas vezes invertendo os polos das análises elaboradas pela historiografia oitocentista no que se refere, sobretudo, aos eventos de forte identificação regional. Do ponto de vista da escrita da história, ainda segundo Maria Aparecida Silva de Souza, os integrantes do IGH eram responsáveis pelos trabalhos históricos, com destaque para Braz do Amaral e Francisco Borges de Barros, "adotavam uma metodologia assentada na visão da cientificidade da história, conferida por sua base documental - o que pressupunha a admissão da veracidade dos acontecimentos relatados por esta documentação" (SOUSA, 2005: $187)^{7}$

Do ponto de vista político, os mesmos historiadores do IGH buscaram os exemplos do passado que pudessem solidificar o sentimento patriótico para promover a recuperação da história baiana em uma conjuntura política bastante específica. Segundo os discursos dos beletristas, o IGH “coligirá e estudará, para arquivar e publicar, as tradições e documentos que puder obter, concernentes à geografia e à história, à arqueologia, à etnografia, às línguas indígenas do Brasil, especialmente deste Estado" (RIGHB, n. 46, vol. XXVII, Salvador, 1920: 4 apud SOUSA, 2005: 186). Com efeito, Francisco Borges de Barros (1922) e Braz do Amaral $(1941)^{8}$, inspirados ainda pela concepção tradicional e factual da prática historiográfica oitocentista, interpretaram a Conjuração Baiana de 1798 em perspectivas distintas, mas com um objetivo em

\footnotetext{
${ }^{6}$ Veja-se SOUSA, Maria Aparecida Silva de (2005). História, memória e historiografia: abordagens sobre a Independência na Revista do Instituto Geográfico e Histórico da Bahia (1894-1923). Politéia: História e Sociedade, Vitória da Conquista, vol. 5, n.1, pp. 177-195. Segundo a autora, em 1856, ocorreu a fundação do Instituto Histórico Provincial da Bahia, que, todavia, seria fechado pouco tempo depois. Cf. p. 180. Instituto Geográfico e Histórico da Bahia, doravante IGH.

${ }^{7}$ Cláudia R. Callari (2001) demonstra o mesmo padrão de escrita da história nos quadros do Instituto Histórico e Geográfico de Minas Gerais.

${ }^{8}$ Ver as anotações do autor na obra de Inácio Accioli de Cerqueira e Silva. Memórias Históricas e Políticas da Província da Bahia. Salvador: Imprensa Oficial do Estado da Bahia, 1931, 6 vols.
} 
comum: ressaltar a vocação republicana dos baianos dos tempos idos e demarcar a posição política do Estado da Bahia no processo de formação do Estado brasileiro.

Isso porque, instalada a República por decreto, o 15 de novembro marcou o desfecho de um movimento que quase não teve nenhum contato com as forças populares, resultando em um golpe militar que precisava de legitimação, conforme analisou José Murilo de Carvalho ${ }^{9}$. A historiografia republicana carioca consagrou Tiradentes como o herói nacional e, desde a década de sessenta do século XIX, o republicanismo identificado nos movimentos de contestação ocorridos em Minas Gerais e na Bahia, no final do século XVIII, já não era um projeto político de nação interdito.

Aproveitando as trilhas abertas pela historiografia do IHGB, sobretudo as obras elaboradas durante o segundo Reinado sobre análises das revoltas coloniais ocorridas no final do século XVIII, que se configurou uma importante ideologia patriótica para a consolidação de algumas implantações do regime republicano, especialmente em relação às tradicionais oligarquias regionais ${ }^{10}$. Com efeito, se por um lado a historiografia do IHGB consagrou Tiradentes como o herói nacional, por outro, a historiografia do IGH mostrará a sua contribuição enaltecendo seus heróis regionais e o papel desempenhado pela então elite local nas lutas pela Independência do Brasil na Bahia.

\section{Francisco Borges de Barros}

Francisco Borges de Barros foi diretor do Arquivo Público da Bahia e o primeiro Grão-Mestre da Grande Loja da Bahia, a primeira a ser fundada no Brasil, após a cisão de 1927. Francisco Borges de Barros é autor de vários trabalhos sobre a Bahia, mas

\footnotetext{
${ }^{9}$ Cf. CARVAlHO, José Murilo de. A Formação das almas: o imaginário da República no Brasil. São Paulo: Companhia das Letras, 2001, $11^{\mathrm{a}}$. reimpressão. Ver o capítulo 3: Tiradentes: um herói para a República, pp. 55-74.

${ }^{10}$ Wilma Peres Costa chama atenção, sem aprofundar a questão, para o papel ideológico da historiografia regional como um dos caminhos possíveis para a resolução da crise política das oligarquias regionais em relação ao papel das economias rurais numa ordem econômica capitalista. Contradição essa que, de acordo com as análises de Francisco de Oliveira e Luiz Felipe de Alencastro, entre outros, começou a ser definitivamente resolvida com a Revolução de 1930 e com a criação da SUDENE. Cf. COSTA, Wilma Peres, op.cit., p. 67. Veja-se a esse respeito: OLIVEIRA, Francisco de. A questão regional: a hegemonia inacabada. Estudos Avançados, vol. 7, n. 18, Maio-Junho, São Paulo, pp. 43-63; Elegia para uma re(li)gião: Sudene, Nordeste, planejamento e conflito de classes. Rio de Janeiro: Paz \& Terra, 1977; ALENCASTRO, Luiz Felipe de. Memórias da Balaiada: introdução ao relato de Gonçalves de Magalhães. Novos Estudos Cebrap, São Paulo, n. 23, 1989, pp. 7-13.
} 
nobilitou-se na cena historiográfica, sobretudo, pelas obras Os confederados do Partido da Liberdade: subsídios para a história da Conjuração Baiana de 1798-1799 (1922) e Primórdios das Sociedades Secretas na Bahia (1929). Foi na obra Os confederados do Partido da Liberdade que Francisco Borges de Barros versou sobre a Conjuração Baiana de 1798.

O objetivo geral da obra, segundo o autor, era demonstrar as consequências das causas econômicas e sociais internas da Salvador de 1798, somadas à contingência das ideias francesas que, a seu ver, "abrira[m] novos horizontes à vida dos povos" (BARROS, 1922: 20), fazendo com que o espírito público fosse "se erguendo contra o throno". No item Symptomas de uma época, seguindo o padrão das obras que até então trataram do evento, Francisco Borges de Barros inicia o tema a partir das ações do governador d. Fernando José de Portugal e Castro, valendo-se do trabalho do primeiro diretor do Arquivo Público do Estado da Bahia, Francisco Vicente Viana.

Após enumerar uma série de medidas tomadas por d. Fernando José de Portugal e Castro, durante os anos finais do século XVIII, Borges de Barros afirma que não podia fazer a "história dessa sedição sem estudar a situação política de Portugal" (BARROS, 1922: 5). O autor descreve, então, as dificuldades diplomáticas e financeiras de Portugal, durante os anos de 1797-1799, afirmando que "agudíssima era a crise econômica e financeira, desapparecendo a moeda mettalica deante da invasão do papel". Corroborava para aumentar o momento de "crise", segundo o autor, o fato de que "cercava d. Rodrigo uma camarilha ventruda, que procurava alapardar os lucros da ourama que sahia dos veeiros lassos do Brasil”. A situação econômica e financeira de Portugal, de acordo com o autor, foi a razão pela qual a justiça vivia subordinada aos maus funcionários, fazendo com que a "prevaricação dos juízes [atingisse] até a colônia brasileira" (BARROS, 1922: 5-6).

Depois de demonstrar muito rapidamente a situação de Portugal no final do século XVIII, Francisco Borges de Barros passa a tratar da situação específica da Bahia na época. No item "A exorbitância dos impostos - contrabandos - a lassidão dos costumes - o abandono", o autor afirma que os impostos "asphyxiavam" a vida do povo e eram anualmente aumentados. Entretanto, a pesada carga tributária da Coroa, “como o subsídio literário, lançado para manter o estudo do latim e da geometria, eram desviados para fins diversos dos que determinarão sua creação" (BARROS, 1922: 6). Francisco 
Borges de Barros passa, em seguida, a descrever todos os impostos pagos pelo "povo" da Capitania, para dedicar-se à polêmica do comércio a retalho.

De acordo com o autor, no ano de 1797, chegaram a Salvador mais de 80 mascates que logo iniciaram o comércio de uma grande variedade de sedas vindas da Índia e de finíssimos panos brancos que eram vendidos a baixo preço porque os produtos não tinham passado pela Alfândega. O contrabando de sedas e tecidos, segundo o autor, explicava a corrupção dos costumes da sociedade baiana da época, uma vez que "negros e mulatos, dos mais remediados, vestiam seda e faziam concorrência aos brancos nas festas do verão, na cidade" (BARROS, 1922: 7). Razão pela qual o Senado da Câmara reivindicou providências ao governador, que foram rapidamente tomadas.

Segundo Francisco Borges de Barros, após a elucidação do caso do comércio a retalho, a devassa da "Alfândega" e a proibição dos vendedores ambulantes, "a perseguição dos mulatos crescia dia-a-dia", quando, a seu ver, o governador deveria ter tomado providências contra os "abusos praticados pelos Ouvidores e Juízes de Fora, os quaes gastavam em rega-bofes as rendas dos processos" (BARROS: 1922: 9). Colaborou para a já "afflictissima" situação da Bahia o fato de que no ano de 1798 era grande o rendimento de fumo, motivo pelo qual o governo determinou por carta régia que fosse lançado em caráter obrigatório "o empréstimo de papel moeda na importância de três milhões de cruzados e juros de 6\%" (BARROS, 1922: 9), seguindo-se a recusa dos negociantes das principais casas do comércio.

Em seguida, Francisco Borges de Barros afirma que "feito o balanço das forças econômicas e bem caracterizadas a afflictissima situação da Capitania chegaram os povos à conclusão de não ser mais possível adaptarem-se às injunções do momento". Assim, em As origens do movimento revolucionário, o autor entra de fato na discussão sobre a revolta baiana de 1798, afirmando inicialmente que "a dispersão das ideias era reflectora de uma época de decadência e opressão", para em seguida retomar o argumento de John Armitage sobre o papel da Revolução Francesa que, de acordo com Borges de Barros, trouxe um "largo contingente de idéias novas" e "fechara um cyclo histórico e abrira novos horizontes à vida dos povos" (BARROS, 1922: 20). Mesmo com um forte esquema repressivo das autoridades locais para barrar qualquer propaganda ou folheto com notícias da França revolucionária, para o autor "dest'arte, o espírito público ia se erguendo contra o throno". 
Apesar da fiscalização régia, as ideias libertárias ligaram num mesmo elo, segundo Borges de Barros, maranhenses, pernambucanos e baianos. Isso porque, no ano de 1797, "fundaram na ponta da Barra a Loja 'Cavalheiros da Luz', primeiro templo maçônico da Bahia". Neste particular, Francisco Borges de Barros abre uma polêmica que até hoje não foi resolvida na historiografia que versa sobre a Conjuração Baiana de 1798. O historiador publicou, em 1928, no volume XV dos Anais do Arquivo, nas páginas 44 e 45, a história da loja "Cavaleiros da Luz", afirmando categoricamente a fundação da loja maçônica, sem, contudo, apresentar prova documental. O autor valeuse apenas do fato de ter sido um dos fundadores da Loja Maçônica da Bahia, em 1927, e de afirmar nas reuniões do IGH que tinha lido alguns documentos da Maçonaria, e, dado o caráter secreto da loja, não seria possível publicá-los ${ }^{11}$.

Essa polêmica, entretanto, não é de pouca relevância uma vez que a fundação e a existência da referida loja passaram a integrar o conjunto de eixos de significação da Conjuração Baiana de 1798. Neste sentido, para Borges de Barros, a Maçonaria passa a ser o centro difusor de ideias e práticas dos agentes do evento. Tanto mais que, após afirmar, sem comprovação documental, a existência da Loja Maçônica Cavalheiros da Luz, Borges de Barros resgatará os possíveis fundadores da loja, associando-os aos partícipes da Conjuração Baiana de 1798.

Sobre a participação de homens importantes da sociedade baiana no evento, que, a seu ver, seriam também os fundadores dos Cavaleiros da Luz, cumpre destacar uma observação de Francisco Borges de Barros, escrita na obra Primórdios da Sociedade Secreta na Bahia. Afirma o autor:

Em princípios de julho de 1797 ancorava na Bahia a fragata La Preneuse, que havia sustentado um combate com a corveta portuguesa Santo Antonio Polyphemo, de que era comandante Manoel Nascimento Costa [...]. Naquela fragata houve inúmeros entendimentos pelos homens mais esclarecidos da terra, e dessas confabulações fizeram parte: José da Silva Lisboa, o padre Francisco Agostinho Gomes, Cypriano Barata, Ignácio Bulcão, Francisco

\footnotetext{
${ }^{11}$ Veja-se a respeito da polêmica sobre a fundação da loja "Cavaleiros da Luz", CASTELLANI, José. A polêmica em torno da fundação da primeira loja maçônica do Brasil: uma novidade bastante antiga. Revista Acácia, Porto Alegre, 1995. Agradeço ao Prof. José Castellani a indicação do artigo, bem como algumas informações a respeito da loja maçônica. Sobre a sociabilidade maçônica no período da Independência, ver, especialmente: BARATA, Alexandre Mansur. Maçonaria, Sociabilidade Ilustrada e Independência do Brasil (1790-1822). São Paulo/Juiz de Fora: FAPESP/Annablume-EDUFJF, 2006.
} 
Muniz Barreto e o tenente Hermógenes de Aguiar Pantoja, por ter pretendido dar um jantar aos franceses. De Francisco Muniz Barreto há uma parte interessante de seu depoimento 'que havendo estado na capital em 1797 freqüentou a casa de José Borges de Barros, seu vizinho, há pouco chegado da Ilha da Madeira, o qual era irmão de Domingues Borges de Barros, e muitas vezes conversou com o primeiro sobre o governo econômico da terra, assim como sobre as notícias que chegavam do estado político da Europa'. Este o estado de espíritos sequiosos de liberdade, humanidade e igualdade, quando aos 14 de julho de 1797 Larcher e os brasileiros citados fundaram na povoação da Barra a loja maçônica Cavalheiros da Luz [...] (BARROS, 1929: 45).

Não parece ser por outra razão que o autor afirma que "pelas investigações feitas, chegamos à conclusão de que três homens dirigiram [...]" a revolta baiana de 1798: José da Silva Lisboa, "o organisador calmo, meditado e prudente"; Cipriano Barata de Almeida, "o agitador das ruas [...] idealista e mais sensível que intelligente"; e Francisco Agostinho Gomes, "um santo e um sábio" (BARROS, 1922: 21). José da Silva Lisboa (1756-1831), inclusive, merece um item à parte na obra de Francisco Borges de Barros: "o povo - apparece a figura de José da Silva Lisboa". Nesse item, o autor afirma que dos partícipes do evento "acoroçoavam a fina flor da sociedade bahiana", e dos três líderes da revolta baiana de 1798, citados acima, cumpre destacar a personalidade de José da Silva Lisboa, que por ser "organizador calmo, meditado e prudente", ergueu uma bandeira de reivindicações e disseminou "os sentimentos da pátria que agitaram a grande colônia” (BARROS, 1922: 21).

Quanto à participação de homens dos mais baixos setores da sociedade baiana da época, nomeadamente João de Deus do Nascimento e os demais homens enforcados e esquartejados em praça pública, Borges de Barros afirma que eles tiveram o mesmo papel que Tiradentes: "foram, como em todas as revoluções, collocados na linha de frente" (BARROS, 1922: 21). Isso porque, a seu ver, "as idéias de igualdade embutidas aos pardos e pretos lhes affiançavam o bom êxito pelo argumento considerável de seu partido" (BARROS, 1922: 22). Neste particular, o autor inaugura a perspectiva de análise que tem como ponto de partida a "influência das ideias francesas", difundidas em reuniões da maçonaria por membros da "fina flor da sociedade baiana", como a cadência dos partícipes da revolta baiana de 1798, pois “o livro 'Ruínas', de Volney, 
vários pamphletos e avulsos, inspirados na grande conquista da revolução francesa, eram o catecismo dos sediciosos".

Como para o autor os setores médio e baixo, envolvidos na revolta baiana de 1798, não teriam nenhuma expressão ou participação significativa nos acontecimentos, Borges de Barros encaminha o desfecho da análise carregando na tinta a participação de pessoas proeminentes daquela sociedade. Nesse sentido, ele afirma mais uma vez que, entre os partícipes da revolta, "acoroçoavam a fina flor da sociedade bahiana", uma vez que os senhores de engenho "não eram estranhos ao movimento". Para comprovar a afirmação e enaltecer José da Silva Lisboa e Cipriano Barata como as "cabeças pensantes do movimento", Borges de Barros transcreve, na obra, trechos de uma carta entre os dois baianos ilustres, segundo a qual Silva Lisboa escreve para Cipriano Barata, do seu retiro de Maré, que:

No estado em que se acha Portugal devemos aproveitar a ocasião para proclamar a independência da capitania. Já deve estar na barra uma esquadra francesa que vem ao nosso auxílio, e deve estar avisado o professor do Rio de Contas, que traz a expedição de mil homens. Ninguém há de lhe dizer a verdade como eu, nem interessar-se tanto pelo bem público. Já o José Pires de Albuquerque [Secretário de Estado e Governo do Brasil] lhe deve ter comunicado a resolução dos nossos amigos do Recôncavo. Tenha cuidado com o frei José [do Monte Carmelo] e frei Francisco na disputa que mantém quanto ao querer cada qual ser o chefe da Igreja. Por carta de Marcelino Antônio sei que está firme. Estou a escrever os artigos do programa de governo $^{12}$.

O autor termina sua interpretação sobre a revolta baiana de 1798 transcrevendo alguns trechos dos depoimentos dos réus, nos quais há referência, de uma forma ou de outra, às atuações de José da Silva Lisboa, Cipriano Barata e o padre Francisco Agostinho Gomes (BARROS, 1922: 30 et. segs.). Francisco Borges de Barros, ao

\footnotetext{
12 BARROS, Francisco Borges de não cita a referência de nenhum documento pesquisado para a interpretação da Conjuração Baiana de 1798. Limita-se apenas a escrever: Arquivo Público do Estado da Bahia. Contudo, esta carta de José da Silva Lisboa a Cipriano Barata é citada na íntegra por Affonso Ruy e Florisvaldo Mattos, sem a referência documental. O recuso utilizado pelos os autores é a afirmação "documento citado por Francisco Borges de Barros". A esse respeito, veja-se, respectivamente: RUY, Affonso. A primeira Revolução Social Brasileira (1798). São Paulo: Companhia Editora Nacional; Coleção Brasiliana, vol. 217, 1942, p. 54; MATTOS, Florisvaldo. A comunicação social na Revolução dos Alfaiates. Salvador: Assembleia Legislativa da Bahia: co-edição Academia de Letras da Bahia, 1998, p. 135 .
} 
afirmar como os principais membros da revolta baiana de 1798 homens que também fundaram a primeira loja maçônica na Bahia, objetivou destacar o papel de alguns baianos ilustres da Maçonaria no processo de Independência do Brasil, em 1822.

A esse respeito, cumpre ressaltar que a grande ênfase nas obras elaboradas nos quadros do IGH, durante a comemoração do primeiro centenário da Independência do Brasil, é o período considerado pelos historiadores da agremiação como o de maior glória para o povo baiano: “a resistência da província durante a guerra civil entre portugueses e brasileiros nas lutas pela Independência do Brasil no decorrer dos anos de 1822-1823". Nesse empuxo, a produção historiográfica do IGH, na segunda década do século XX, é caracterizada, sobretudo, por deslocar o marco da proclamação da Independência do grito do Ipiranga, 7 de setembro, para o 2 de julho de 1823, como um marco inconteste ${ }^{13}$.

Nesse processo de estabelecimento de novos eixos cronológicos da Independência do Brasil, entre os trabalhos publicados na revista do IGH, chama a atenção, em primeiro lugar, o número de artigos dedicados às ilustres pessoas no cenário regional durante o período das lutas da Independência na Bahia e durante o Império. Entre os baianos ilustres, cabe ressaltar que José da Silva Lisboa, o Visconde de Cairu, é, sem sombra de dúvidas, a figura de maior destaque. Não parece ser por outra razão que Francisco Borges de Barros considera José da Silva Lisboa ${ }^{14}$ como um dos líderes intelectuais da revolta de 1798, para, em seguida, demonstrar em sua análise que o sentimento patriótico começava a despertar entre os baianos ilustres já nas décadas finais do século XVIII.

Uma das razões para o Visconde de Cairu ter sido um dos principais mentores da Independência do Brasil, na interpretação de Francisco Borges de Barros sobre a Conjuração Baiana de 1798, para além do fato de José da Silva Lisboa ter sido GrãoMestre da Maçonaria, durante o primeiro Reinado, talvez esteja ligada à situação da elite baiana durante a Primeira República. A posição que a Bahia passou a ocupar na ordem republicana ocasionou acentuado desconforto em suas elites. É bom destacar que

\footnotetext{
${ }^{13}$ Cf. Sousa (2005: 187). A esse respeito, veja-se também: AMARAL, Braz do Amaral. História da Independência na Bahia. Salvador: Progresso, 1957; KRAAY, Hendrik. Entre o Brasil e a Bahia: as comemorações do 2 de julho em Salvador, século XIX. Afro-Ásia, Salvador, n. 23, 2000: 49-87; REIS, João José. A elite baiana face aos movimentos sociais, Bahia (1824-1840). São Paulo: Difel, 1985: 242311; TAVARES, Luís Henrique Dias. História da Bahia. São Paulo/Salvador: Unesp/Edufba, 2001.

${ }^{14}$ José da Silva Lisboa, apesar de ser considerado por alguns historiadores como um católico fervoroso por seus escritos, a partir da fundação da Ordem Maçônica do Grande Oriente do Brasil, em 1822, cujo primeiro Grão-Mestre foi Pedro I, e, depois, o próprio José da Silva Lisboa durante o primeiro Reinado. Cf. CASTELLANI, José Castellani, op.cit.; ROCHA, Antônio Penalves, op.cit.
} 
durante o Império, políticos baianos exerceram vários cargos administrativos de relevo, especialmente as pastas ministeriais. De acordo com alguns autores, a terça parte de todos os chefes de gabinete do Segundo Reinado e a quarta parte de todos que foram nomeados Ministros de Estado, no mesmo período, tiveram origem na Bahia. Sem contar que até meados do oitocentos a Bahia perfilava entre os três principais centros econômicos do país.

Já no período 1889-1930, a Bahia se tornou coadjuvante no cenário político e econômico nacionais, provocando um grande desconforto na elite regional, que alegava viver uma crise, cujos sinais eram o "declínio econômico" e a "decadência política"15. Durante o período da Primeira República, a Bahia apenas elegeu um vice-presidente no primeiro governo civil - Manoel Victorino, na presidência de Prudente de Morais (1894-1898) -, e até o ano de 1930 a Bahia foi mal sucedida todas as vezes que lançou candidatos à presidência. Nesse período, com efeito, as elites manifestavam seus descontentamentos culpando a ineficácia do novo regime como uma das causas de seu declínio político Não parece ser por outra razão que as elites baianas da Primeira República procuraram engendrar formas de reivindicar e marcar posição junto aos principais núcleos políticos nacionais, nomeadamente São Paulo, Minas Gerais e Rio Grande do Sul.

E a História da Bahia, nesse processo, configurou-se como uma importante ferramenta no que se refere ao reconhecimento das antigas tradições de luta e participação política dos soteropolitanos "ilustres" no processo de construção da Nação e do Estado brasileiros ${ }^{16}$. Assim, para além do anacronismo de qualificar as ações de José da Silva Lisboa, Cipriano Barata e o padre Francisco Agostinho Gomes como um desejo de independência do jugo metropolitano, ao enaltecer o papel desempenhado pelo Visconde de Cairu, Francisco Borges de Barros considerou o desfecho do processo de emancipação política do Brasil, durante o período de 1822-1823, emprestando papel proeminente ao Visconde, durante o período imperial ${ }^{17}$.

\footnotetext{
${ }^{15}$ Sobre a hegemonia política baiana no Império, ler: MATTOSO, Kátia M. de Queiros. Bahia, século XIX: uma província do Império. Rio de Janeiro: Nova Fronteira, 1992; CARVALHO, José Murilo de. A construção da ordem: a elite política imperial; O teatro das sombras: a política imperial. Rio de Janeiro: Editora da UFRJ/Relume-Dumará, 1996; HOLANDA, Sérgio Buarque de. O Brasil Monárquico: do Império à República. São Paulo: Difel, 1983.

${ }^{16}$ Cf. VAliM, Patrícia. Da Sedição dos Mulatos à Conjuração Baiana de 1798: a construção de uma memória histórica. Dissertação de Mestrado, DH/FFLCH/USP, 2007.

17 A respeito da atuação política do Visconde de Cairu durante o período imperial, especialmente no primeiro Reinado, veja-se: Antônio Penalves Rocha, op.cit. Chamamos atenção para o fato de que para Affonso Ruy, muito provavelmente Francisco Borges de Barros confundiu-se na leitura do depoimento do soldado Ignácio Pimentel, um dos acusados, no qual é citado o nome Silva Lisboa. Para Affonso Ruy,
} 
Por outro lado, Francisco Borges de Barros diz muito pouco sobre a atuação dos homens livres, pobres e pardos, e os cativos que foram presos no Segredo da Relação, acusados de participarem da revolta. Se o autor comparou os réus enforcados e esquartejados em praça pública a Tiradentes, à época já considerado um herói nacional, foi porque, como o autor não faz nenhuma referência documental, muito provavelmente não citá-los em sua obra comprometeria a verossimilhança da interpretação. Depois, Tiradentes era considerado herói nacional, mas, como se sabe, sua atuação tinha sido em Minas Gerais.

Levando-se em conta a interpretação que o IGH elabora sobre as lutas pela Independência do Brasil na Bahia, não parece ter sido por outra razão que Francisco Borges de Barros, em certo momento de sua interpretação, compara a Conjuração Baiana de 1798 à Inconfidência Mineira de 1789. A respeito da comparação dos réus enforcados, homens livres, pobres e pardos, a Tiradentes, e a participação da "fina flor da sociedade da época" com os homens livres e pobres que foram à linha de frente da revolta, cumpre destacar que essa interpretação de Borges de Barros foi considerada, a partir da década de setenta do século XX, como um indicativo importante de cooperação de classe.

Na introdução historiográfica sobre a Conjuração Baiana de 1798, elaborada por István Jancsó, a interpretação de Francisco Borges de Barros sobre o evento significa que "o ideal de cooperação de classe já é um valor que se faz presente" (JANCSÓ, 2001: 301) na relação entre as ideias de igualdade pensadas e divulgadas por homens maçons que orientaram as atitudes dos homens livres, pobres e pardos que foram enforcados e esquartejados em praça pública. Tal relação não chega a ser um ideal de cooperação de classe se considerarmos, por um lado, a ideia de "liberdade" dos próprios agentes (JANSÓ, 2001: 301; VALIM, 2019: 53-49) e, por outro lado, que Francisco Borges de Barros sugere em sua análise que a propagação das ideias da Revolução Francesa foi uma estratégia política extremamente eficaz de homens como José da Silva Lisboa, Cipriano Barata e Francisco Agostinho Gomes para arregimentar, "cooptar" maior número de participantes de vários setores daquela sociedade.

trata-se de Antônio da Silva Lisboa e não José da Silva Lisboa, o Visconde de Cairu. Essa informação se fosse comprovada invalidaria a análise de Francisco Borges de Barros sobre a Conjuração Baiana de 1798, especialmente no que se refere à participação e atuação do Visconde de Cairu no evento. Cf. Affonso Ruy. A primeira Revolução Social Brasileira. São Paulo: Companhia da Editora Nacional, 1942, p. 118 . 
A esse respeito, cabe lembrar que o desejo de liberdade dos homens livres pobres e dos cativos é mobilizado por Francisco Borges de Barros, e mesmo pelas autoridades locais em 1799, para justificar a pena imputada aos quatro homens considerados como os líderes da revolta ${ }^{18}$. Tanto mais que sobre os escravos e os demais milicianos e alfaiates Francisco Borges de Barros nada escreve a respeito. No entanto, István Jancsó afirma que o ideal de cooperação de classe na análise está ligado com as premências do capitalismo periférico e a emergência de uma nova ordem política cujo ensaio ocorreu na Conjuração Baiana de 1798 e que, ao fim e ao cabo, está relacionada com o fato de que uma nação republicana era projeto de todas as classes da sociedade baiana da época.

Ainda que a análise nos remeta a uma ideia caricatural do processo do fim do Império e da consolidação da República, Renato Lessa demonstra que há uma tendência de parte da historiografia brasileira do século XX de afirmar que "as crises políticas só fazem sentido, em certa concepção, se são a ponta aparente de determinações fundas na estrutura social, na econômica e na de classes. A ideia é a de que essa estrutura - o capitalismo ou algo semelhante - teria interpelado o Império e exigido a República" (LESSA, 2000: 9-38).

Seja como for, a interpretação de Francisco Borges de Barros sobre a Conjuração Baiana de 1798, como se viu, liga-se a uma circunstância na qual há inúmeros discursos publicados na revista do IGH, que reivindicavam uma efetiva participação dos baianos ilustres na fundação da nação brasileira. De modo geral, os historiadores baianos da agremiação, durante a Primeira República, ressaltavam que "foi na Bahia onde a guerra de Independência se travou primeiro e [foi] mais cruenta. O grito do Ipiranga - Independência ou morte - foi precedido pelo brado de Cachoeira Independência ou morrer - repetido na cantinela patriótica" (RIGHB, n. 46, vol. XXVII, 1920 apud SOUSA, 2005: 192). Essa era a ideia corrente entre os beletristas soteropolitanos, retomada na interpretação que Braz Hermenegildo do Amaral elaborou sobre a Conjuração Baiana de 1798.

\footnotetext{
${ }^{18}$ Cf. VALIM, Patrícia Valim. Corporação dos enteados: tensão, contestação e negociação política na Conjuração Baiana de 1798. Salvador: EDUFBA, 2018.
} 


\section{Braz Hermenegildo do Amaral}

Braz Hermenegildo do Amaral (1861-1949) era filho homônimo de Braz Hermenegildo do Amaral e de D. Josefina Virgínia do Amaral. Seu pai, capitão de polícia, foi combatente na Guerra do Paraguai, cujo desempenho lhe rendeu várias congratulações. Não obstante os feitos militares de seu pai, Braz do Amaral teve uma infância muito pobre, de tal sorte que cursou a Faculdade de Medicina da Bahia, uma das primeiras do país, enquanto lecionava no Colégio da Bahia. Tornou-se professor da Faculdade de Medicina e, como tal, integrou o corpo médico das Tropas Oficiais na Guerra de Canudos. Enquanto lecionava, Braz do Amaral dedicou-se à pesquisa e publicação de trabalhos sobre a historiografia baiana.

Com bastante trânsito na vida pública, especialmente no período em que Rodrigues Alves foi Presidente, Braz do Amaral ocupou a legislatura federal, pelo Partido Republicano, por dois mandatos, durante os períodos de 1924-1926 e 1927 1929. Foi um dos fundadores do Instituto Geográfico e Histórico da Bahia, ocupando inclusive diversos cargos diretivos na agremiação. Como membro-fundador da Academia de Letras da Bahia, Braz do Amaral ocupou a cadeira 4, cujo Patrono é outro ilustre historiador baiano, Sebastião da Rocha Pitta. Braz do Amaral nobilitou-se na historiografia nacional por obras que versam sobre os limites e os aspectos políticos da Bahia e, sobretudo, por suas anotações às obras de Inácio Accioli de Cerqueira e Silva e Luís dos Santos Vilhena ${ }^{19}$. Foi na obra Conspiração Republicana da Bahia de 1798 que Braz do Amaral interpretou o evento (1927).

Braz do Amaral inicia sua análise afirmando que a revolta baiana de 1798 era um movimento muito pouco conhecido, porque os autores dos compêndios históricos de sua época reproduziam o que os “outros já escreveram”, e, como o gosto das investigações históricas ainda não era corrente entre os historiadores, "ficou esta tentativa de independência do Brasil, quase ignorada dos brasileiros [...]". Para o autor, entretanto,

a Conjuração Baiana é episódio de notável relevo na vida deste povo, porque constitui prova irrefutável de que se fazia um movimento com instintos libertários em todo o país, nos fins do século XVIII e princípios do XIX, o qual apresenta três grandes expoentes, a saber: a conspiração de Minas

\footnotetext{
${ }^{19}$ Cf. Dicionário de Autores Baianos. Salvador: Secretaria de Cultura do Governo da Bahia, 2006.
} 
Gerais em 1792, chamada também de Tiradentes, a conspiração da Bahia de 1798 e a revolução de Pernambuco de 1817. Vê-se que não devem ser isolados estes três fatos, pois todos tiveram a mesma causa determinante (AMARAL, 1927: 5).

Para Braz do Amaral, tomadas em seu conjunto, as revoltas do final do século XVIII se "concatenam e são sintomas de um estado político e social que foi o que teve finalidade em 1823, porque todos foram orientados pela aspiração que tinham os brasileiros de mudar a forma de governo" (AMARAL, 1927: 5). De acordo com a análise do autor, "a conjuração baiana [...] já se revelou mais importante que a primeira [Inconfidência Mineira de 1789]" porque ela é "mais digna de nota", pois demonstra uma "fase mais adiantada do movimento liberal e porque abrangeu um número muito maior de implicados, o que prova a extensão que ia tomando o anseio de independência dos nacionais, ainda demonstrando como se firmava a propaganda dos princípios de liberdade, tanto civil como religiosa" (AMARAL, 1927: 6).

A relevância do evento se justifica, segundo o autor, porque entre os partícipes havia "não somente pessoas das classes elevadas da colônia, mas homens das classes que constituem a massa de uma nação, que nem os castigos severos, nem a supressão de notícias, nem os outros meios empregados, puderam impedir que a causa continuasse a conquistar inteligências e corações" (AMARAL, 1927: 6-7).

Após afirmar que já se sentia, em 1798, "a alma do povo", Braz do Amaral caminha pela trilha aberta pela historiografia do IGB, ao enaltecer as lutas da Independência na Bahia, cujo marco cronológico da Independência foi deslocado para 02 de julho de 1823, e afirma que a revolta baiana de 1798 não foi inútil porque ela "repercutiu onde devia repercutir, pois isto se deu na capitania, no local em que foi preciso sacrifício, esforço e constância para levar a efeito a independência, visto como na Bahia a transformação política não se operou sem luta, não foi realizada pelo governo, à frente do qual achava-se o príncipe regente [...]” (AMARAL, 1927: 7).

$\mathrm{O}$ autor procura ressaltar a Bahia como um foco de luta, resistência e anseio de mudanças políticas. Entretanto, diferencia-se de Francisco Borges de Barros ao afirmar que "a qualidade dessa conspiração [foi] formada no seio do povo", fato indicativo de que a propaganda das "ideias liberais ia ganhando o terreno em todas as camadas da sociedade". Neste particular, o autor aponta a "influência" das ideias propagadas pela Revolução Francesa, para afirmar que: 
a semente colhida nos livros franceses e nas notícias que chegavam a alguns, logo a outros transmitidas, dos acontecimentos revolucionários da Europa e da América, sempre avidamente recebidas, produziram a germinação do movimento de Minas, nascido entre homens de inteligência [...]. Apesar de arrancada dali, veio a brotar em outro ponto [Bahia] por indivíduos a que as mesmas doutrinas tinham seduzido, apaixonadas pela causa da emancipação dos povos e pela esperança de libertar o seu (AMARAL, 1927: 7).

Braz do Amaral constrói a interpretação sobre a Conjuração Baiana de 1798 como um exemplo a ser seguido, para sugerir que eventos como esse e a Inconfidência de Minas de 1789 foram o ponto de partida para que "espíritos clarividentes" elaborassem algumas reformas, durante as primeiras décadas do século XIX. O exemplo citado pelo autor é Silvestre Pinheiro Ferreira, que propôs "a separação administrativa da sua metrópole, constituindo uma monarquia dual, o que é indício de que possuía opinião segura da necessidade desta reforma [...]”. Como Braz do Amaral considera que a coroa portuguesa só atendeu incompletamente os anseios de reforma, quando o Brasil foi elevado à categoria de Reino Unido, não compreendendo que "as reformas feitas a tempo evitam as revoluções", o governo metropolitano, com efeito, "não conseguiu impedir a separação completa do Brasil”" (AMARAL, 1927: 8).

Feitas as considerações a respeito das causas e consequências da Conjuração Baiana de 1798, Braz do Amaral utiliza a documentação para, em seguida, comprovar as "provas da exposição feita acima". Desse item em diante, nomeadamente da 8 a . página à $67^{\mathrm{a}}$., Braz do Amaral transcreve quase integralmente uma pequena parte da documentação sobre a Conjuração Baiana de 1798: os pasquins sediciosos, parte das denúncias, pequenos trechos dos depoimentos e termos de acusação. Após a escolha das "provas", o autor encaminha a conclusão de sua interpretação, afirmando categoricamente que os documentos acerca da revolta são "pródromos da nossa Independência que, como as grandes reformas pelas quais passam os povos, teve o seu período de preparação". A esse respeito, Braz do Amaral afirma que:

o período que serve de tema a este estudo foi um período de transição, em que os acontecimentos decorreram, logicamente, de outros que os tinham preparado, o que não escapou a espíritos avisados e perspicazes, como o de Silvestre Pinheiro Ferreira, que percebeu não poder durar a 
ordem das coisas existentes até aí tornada incompatível com a capacidade e cultura do povo do Brasil, o que era revelado pelas múltiplas manifestações de descontentamento (AMARAL, 1927: 67, grifo meu).

Como um dos expoentes da política regional da Primeira República, Braz do Amaral afirma que tanto o Ministro da Marinha e Domínios Ultramarinos, no final do século XVIII, d. Rodrigo de Souza Coutinho, como o governador d. Fernando José de Portugal e Castro "opuseram resistência a um sistema liberal que aparecia como sinônimo, naquele tempo, de iniquidade e violências, como era o jacobinismo". Não obstante, como o espírito da reforma não foi contido, os agentes metropolitanos "concorreram para o estabelecimento de um regime político melhor do que o existente até aí, e melhor também do que os dos revolucionários franceses, pois foi escoimado dos excessos terroristas". Nessa perspectiva, os agentes metropolitanos citados "representavam o gênio conservador que, mesmo na derrota, é útil" (AMARAL, 1927: 69), pois "as resistências e restrições feitas ao jacobinismo lhe entravaram a força e neutralizaram" ações como as da fase do Terror da Revolução Francesa.

Braz do Amaral afirma que a atuação das autoridades régias para conter o jacobinismo deveu-se, principalmente, porque:

os interesses dos homens que compõem os governos em face dos vícios que se introduzem nas classes em que se divide a população, pelo enfraquecimento das crenças religiosas, pela dissolução dos costumes e desorganizações da vida de família, e ainda pelo desenvolvimento do luxo, consequência da riqueza, concorrendo todos estes elementos para destruir as bases das sociedades (AMARAL, 1927: 69).

Após descrever o quadro geral das razões para o descontentamento da sociedade baiana de 1798, Braz do Amaral afirma que:

“a propaganda da evolução das ideias torna evidente a aguda necessidade de reformas. Algumas vezes elas vêm a realizar-se lentamente, mas quase sempre são apressadas pelos abalos que se chamam revoluções”. "Não foi, porém, o jacobinismo que substituiu o 
regime absoluto e sim a monarquia moderada ou representativa, fórmula inglesa que todos adotaram".

O autor termina sua análise da Conjuração Baiana de 1798 afirmando que:

graças ao tempo decorrido e graças aos exemplos que temos visto, podemos afirmar que [...] vinte e quatro anos depois destas sentenças e destas sinistras execuções, a independência do país que havia desejado os condenados bahianos se realizou e justamente papel mais importante nela representou um príncipe da família real, neto da mesma senhora e rainha, em cujo nome suas justiças tinham matado e esquartejado. É pena que tais lições não se aproveitem aos que se apoderam do governo dos povos e aos juízes que os servem (AMARAL, 1927: 71).

Diferentemente da interpretação de Francisco Borges de Barros, parece inegável que o ideal de cooperação de classe esteja presente na interpretação que Braz do Amaral fez da Conjuração Baiana de 1798, ainda que em seus estágios iniciais, pois tudo leva a crer que a participação da "massa", ou do "povo", segundo o autor, caminha mais para a ideia de "tutela". Parece inegável também que, pela primeira vez, o processo de Independência do Brasil, em 1822-1823, de acordo com os autores citados, foi a via pela qual a Conjuração Baiana de 1798 foi interpretada. Se Francisco Borges de Barros buscou ressaltar a atuação de alguns baianos ilustres em 1822-1823, considerando, para tanto, a atuação dessas pessoas nos quadros da maçonaria, Braz do Amaral, ao contrário, sugere a participação de pessoas importantes na revolta, sem resolver a questão. Pois tudo leva a crer que este autor buscou demonstrar a generalização do desejo de mudança e reformas da sociedade baiana de 1798 como um todo, mas pelo alto: homens ilustres disseminando as ideias da Revolução Francesa.

Braz do Amaral, como se viu, foi Deputado pelo Partido Republicano por dois mandatos consecutivos. Uma das principais questões discutidas entre o membros do Partido Republicano Baiano era a acomodação e a adaptação da oligarquia rural baiana ao novo regime, sem abrir mão do tradicional jogo político das influências, favores, demonstrações de prestígio e poder, permanecendo, portanto, durante a Primeira 
República, a disputa de poder entre as tradicionais oligarquias ${ }^{20}$. Braz do Amaral não permanece alheio a esse processo. Ao contrário.

A grande questão para o historiador e deputado baiano é que, embora o regime republicano representasse, de início, a vitória do federalismo e da autonomia dos estados, o federalismo da Primeira República acentuou as assimetrias regionais, concentrando renda e poder nos estados mais ricos. Essa realidade repercutiu em vários setores da vida baiana, cujo controle, à época, ainda era exercido pelas oligarquias rurais. Razão pela qual, durante a Primeira República, há várias condenações explícitas ao liberalismo político entre aqueles que se opunham à ordem política estabelecida.

Assim, com base na evidência de que os direitos políticos liberais não se efetivavam em um contexto viciado nas práticas oligárquicas, especialmente nos estados federativos mais pobres, como a Bahia, Elisa Reis demonstra, a partir das teses de Bolívar Lamounier, que a oposição não lutou para a afirmação desses direitos, mas buscou sancionar uma concepção diferente de direitos na qual a coleção de indivíduos, planteada pelo liberalismo, deveria ceder lugar a um indivíduo coletivo, um todo orgânico nacional, tutelado pelo Estado ${ }^{21}$.

Esse processo, como demonstra a autora, caminha para a formação de um sistema ideológico orientado no sentido de conceituar e legitimar a autoridade do Estado como princípio tutelar da sociedade. A autora caracteriza esse projeto autoritário como uma "ideologia de Estado", de forma a contrastá-la com a ideologia do liberalismo clássico. Ainda que os vínculos com as bases socioeconômicas dessa "ideologia de Estado", de fato, fossem extremamente frágeis, a produção intelectual, a partir desse período, teve uma enorme importância, uma vez que trouxe a discussão da construção do Estado e da Nação para o primeiro plano.

Não parece ser por outra razão que essa ideologia autoritária encontrava respaldo não apenas dentro do Estado, mas também em amplos setores da sociedade, anteriormente excluídos da arena política. Essa ideologia, de acordo com a mesma autora, durante a Primeira República, provia justificativa tanto para o fortalecimento do Estado quanto para a incorporação de novos setores sociais que emulavam a nacionalidade (REIS, 1988: 8). Tudo leva a crer que essa seja a chave de entendimento

\footnotetext{
${ }^{20}$ Cf. SAMPAIO, Consuelo. Partidos Políticos da Bahia na Primeira República. Salvador: Editora da UFBA, 1998.

${ }^{21}$ Cf. REIS, Elisa P. O Estado como ideologia. Estudos Históricos, Rio de Janeiro, vol. 1, n. 2, 1988, p. 7
} 
que justifique o fato de Braz do Amaral ter ressaltado a participação de vários setores na Conjuração Baiana de 1798.

Em um artigo intitulado $O$ Federalismo, o autor inicia suas considerações afirmando que:

a Independência do Brasil não se fez apenas com duas frases, o que não fica bem até à dignidade nacional [...] em detrimento da verdade e do reconhecimento do esforço e sacrifícios do povo brasileiro numa luta realmente gloriosa e nobre em que, sem traições, nem quebra nem lealdade, pelo ferro, e pelo sangue se fez a grande obra já preparada no seio da massa popular. Foi ela consequência de uma velha aspiração, como provam as conspirações urdidas em Minas, na Bahia [...] (AMARAL, 1927: 71).

Ressaltar o anseio da "massa", na Independência do Brasil, em 1822, foi um recurso extremamente eficaz no processo de identificação política regional e, pouco tempo depois, no cenário nacional. Isso porque a ideia de cooperação de classe, presente na interpretação de Braz do Amaral sobre a Conjuração Baiana de 1798, ainda que incipiente do ponto de vista conceitual, uma vez que caminha para a ideia de "tutela", muito provavelmente é um dos desdobramentos da ideologia autoritária na qual o Estado passa a atuar como um avalista da coalizão de poder que acomodava as oligarquias rurais tradicionais e o setor industrial emergente no Centro-Sul do país. $\mathrm{O}$ coletivo da sociedade, desejando reformas e mudanças na estrutura de poder, constituindo um dos principais eixos da interpretação que Braz do Amaral fez da Conjuração Baiana de 1798, resolve, no campo ideológico, duas questões muito caras aos anseios regionais na Primeira República.

A primeira delas refere-se ao federalismo. O próprio Braz do Amaral afirma que “a pretensão era separatista" - no sentido de autonomia política. No entanto, na Primeira República, como novamente demonstra Elisa Reis, ao Estado coube o papel de tutor político e econômico com vistas à conciliação dos conflitos entre as tradicionais oligarquias rurais e as elites industriais emergentes. O Estado, nesse sentido, desempenhava um papel estratégico e já se encontrava na posição de regular a entrada de novos elementos na cena política e de exercer um controle tutelar sobre a economia.

Os conflitos decorrentes dessa tensão não foram poucos. Entretanto ainda não eram suficientemente fortes para que as elites industriais do centro-sul formulassem um 
projeto hegemônico alternativo à sociedade agroexportadora, desmobilizando, portanto, os arranjos políticos tradicionalmente estabelecidos. Cabe ressaltar que, à época, os vários setores da economia se confundiam e os interesses se mostravam imbricados, porque, na maioria dos casos, os fazendeiros eram também industriais, banqueiros e exportadores.

Chamamos a atenção para a especificidade desse contexto porque ela nos remete à segunda questão, resolvida no campo ideológico, da interpretação de Braz do Amaral: a cidadania. Novamente é Elisa Reis (1988) quem nos mostra que o poder das oligarquias rurais dependia, em grande medida, da continuidade das relações sociais de produção no campo, as quais precisariam manter a força de trabalho fora da arena política. A situação não era diferente no centro-sul. O que significa que, ainda que a situação fosse redefinida, i.e., a enorme adaptabilidade das oligarquias rurais, dos fazendeiros de café e dos industriais ao novo regime, a estrutura não foi abalada. Práticas oligárquicas se perpetuaram e, ao fim e ao cabo, continuaram impedindo a extensão da cidadania à contingentes mais amplos da sociedade brasileira ${ }^{22}$.

De acordo com José Murilo de Carvalho, a proclamação da República, em 1889, não alterou o quadro, já bastante incipiente, em termos de direitos políticos e sociais do Império. Para o autor, a Constituição republicana de 1891 continuou a excluir do voto os analfabetos, as mulheres, os mendigos, os soldados, os membros das ordens religiosas. Essas contradições foram profundamente agravadas na Bahia; à época, enfraquecida na economia e dividida na política. Essa conjuntura talvez explique o fato de os historiadores baianos concentrarem seus esforços na construção de uma espécie de embate simbólico contra a hegemonia política dos Estados de Minas Gerais e São Paulo, sobretudo no que se refere à participação da elite local - no caso de Francisco Borges de Barros e à participação de amplos setores -, na análise de Braz do Amaral.

Esse processo da historiografia baiana reforçou elementos regionais de forte identificação política, carregando na tinta o papel da Bahia no processo de formação do Estado e da nação. Com isso, a historiografia baiana da Primeira República encontrou um lugar para si na história do Brasil, contrapondo-se, sobretudo, a outros discursos regionais, à época, já suficientemente fortes, como Tiradentes, o mito bandeirante e a ideia de São Paulo como a "locomotiva do país". Daí a comparação da Conjuração

\footnotetext{
${ }^{22}$ Cf. CARVAlHO, José Murilo de. Desenvolvimiento de la ciudadania em Brasil. México: Fondo de Cultura, 1995.
} 
Baiana de 1798 com a Inconfidência Mineira de 1789, o movimento mais representativo do passado mineiro, que se pretendia republicano e nacional ${ }^{23}$.

Coube, portanto, aos historiadores republicanos subverter a ideia oitocentista da punição exemplar em razão do exercício político dos setores médios e baixos, e reforçar os anseios republicanos de amplos setores daquela sociedade para valorizar o papel da Conjuração Baiana no processo de Independência do Brasil e o papel da Bahia na construção do Estado Brasileira. Francisco Borges de Barros e Braz do Amaral demonstraram a vocação republicana "sempre presente" nas remotas ações dos soteropolitanos ilustres absorvida pelos demais setores por meio da maçonaria.

Parece inegável que foi Braz do Amaral quem realmente inverteu os polos das análises oitocentistas ao carregar na tinta do sangue dos réus, homens livres e pobres, enforcados no patíbulo público, em 1799. Nesse processo de inversão historiográfica, o autor procurou demonstrar a generalização e o desejo de independência do domínio português para todos os setores da sociedade de 1798, inaugurando o processo historiográfico que converteria a Conjuração Baiana de 1798 de um evento de grande identificação política regional em um movimento nacional, representante das mais profundas aspirações econômicas e políticas de amplos setores da sociedade.

Embora a análise de Francisco Borges de Barros não seja das mais citadas pela historiografia ulterior ${ }^{24}$, importa reter que o processo de incorporação de homens de distinta condição social, especialmente os setores médios e baixos da sociedade baiana de 1798, excluídos de qualquer participação política, foi a via pela qual Braz do Amaral abriu o caminho para que o evento encontrasse lugar definitivo na história nacional. Lugar esse que será definitivamente consolidado pela historiografia ulterior no que se refere, justamente, à qualificação da articulação entre homens de vários setores da sociedade baiana da época, compreendida como um ideal de cooperação de classes com vistas à Independência do Brasil.

\section{Referências bibliográficas}

\footnotetext{
${ }^{23}$ Cf. CALLARI, Cláudia Regina, op.cit., p. 18.

${ }^{24} \mathrm{Na}$ introdução de seu livro, István Jancsó afirma que a obra de Francisco Borges de Barros é marcada "pela ligeireza no trato da documentação e [pelo] caráter laudatório do texto". Cf. JANCSÓ, Na Bahia contra o Império: a história do ensaio de sedição de 1798. São Paulo: Hucitec, 1996: 21-22.
} 
ABREU, Márcia Abreu e SCHAPOCHNIK, Nelson (Orgs.) (2005). Cultura letrada no Brasil: objetos e práticas. Campinas/São Paulo: Mercado das Letras/FAPESP.

AMARAL, Braz do (1927). A Conspiração Republicana de 1798. Rio de Janeiro, Imprensa Nacional.

. (1957). A história da Independência na Bahia. Salvador: Livraria Progresso Editora, 2a.ed.

ARRUDA, José Jobson de \& PILETTI, Nelson (2000). Toda a História: História Geral e História do Brasil. São Paulo: Ática.

AZEVEDO, Silvia Maria. (2005). Tiradentes ou a canonização de um herói. Patrimônio e Memória. UNESP, FCLAs, CEDAP, vol. 1, n. 1.

BARROS, Francisco Borges de (1922). Os Confederados do Partido da Liberdade. Salvador: Imprensa Oficial do Estado.

- (1929). Primórdios das Sociedades Secretas da Bahia. Salvador, Imprensa Oficial do Estado.

BOURDIEU, Pierre (1989). O Poder simbólico. Rio de Janeiro: Bertrand Brasil.

CALLARI, Claudia Regina (2001) Os Institutos Históricos: do Patronato de D. Pedro II à construção do Tiradentes. Revista Brasileira de História, São Paulo, v. 21, n. 40, p. 62.

CARVALHO, José Murilo de (1980). A construção da ordem: a elite política imperial. Rio de Janeiro: Campus.

HOLANDA, Sérgio Buarque de. (1995). A herança colonial - sua desagregação. In: História da Civilização Brasileira. São Paulo: Difel, vol. 1.

IGLESIAS, Francisco (2000). Historiadores do Brasil: capítulos de historiografia brasileira. Rio de Janeiro/Belo Horizonte: Nova Fronteira/Editora da UFMG.

JANCSÓ, István (1996). Na Bahia contra o Império: história do ensaio de sedição na Bahia de 1798. São Paulo: Hucitec.

(2001). Um problema historiográfico: o legado de D. Fernando José de Portugal. Anais do IV Congresso de História da Bahia, Salvador, Instituto Histórico e Geográfico da Bahia/Fundação Gregório de Mattos, vol. 1.

LE GOFF, J. (1984). Memória. In: Enciclopédia Einaudi., Imprensa Nacional, Casada Moeda, vol. 1.

LESSA, Clado Ribeiro (1954). Vida e obra de Varnhagen. RIHGB, n. 224.

MATTOS, Florisvaldo (1998). A comunicação social na Revolução dos alfaiates. Salvador: Assembleia Legislativa do Estado/Academia de Letras da Bahia, 2a. edição.

MATTOSO, Kátia M. de Queirós (1969). Presença francesa no Movimento Democrático Baiano de 1798. Salvador: Itapuã.

(1992). Bahia, século XIX: uma província no Império. Rio de Janeiro, Nova Fronteira.

(2004). Da Revolução dos Alfaiates à riqueza dos baianos no século XIX. Salvador: Corrupio.

MOTA, Carlos Guilherme (1986). Idéia de Revolução no Brasil. São Paulo: Cortez.

NOVAIS, Faustino Xavier. Os Homens de Lettras. Revista Popular, TomoXII, pp. 327336; Os Homens de Tretas. Revista Popular, Tomo XIII, pp. 327-336;

Os Homens de Tretas. Revista Popular, Tomo XIII, pp. 193-206.

NOVAIS, Fernando Antônio (2001). Portugal e Brasil na crise do Antigo Sistema Colonial (1777-1808). São Paulo: Hucitec, 7a. Edição.

POLLACK, M. (1992). Memória e identidade social. Estudos Históricos, v. 5, nº 10.

RODRIGUES, José Honório (1967). Varnhagen, mestre da história geral do Brasil. RIHGB, vol. 275. 
(1979). História da História do Brasil. Historiografia colonial. São Paulo/Brasília: Companhia Editora Nacional/INL.

SERELLE, Márcio Vasconcelos (1999). No início da História da Conjuração Mineira: o fato e a ficção na construção da obra de Joaquim Norberto de Sousa e Silva. Gragotá, Niterói, n. 6, p. 191.

- (2002). Os versos ou a história: a formação da Inconfidência Mineira no imaginário do Oitocentos. Tese de doutoramento defendida no departamento de Teoria Literária, IEL, UNICAMP.

SOUSA, Maria Aparecida Silva de (2005). História, memória e historiografia: abordagens sobre a Independência na Revista do Instituto Geográfico e Histórico da Bahia (1894-1923). Politéia: História e Sociedade, Vitória da Conquista, vol. 5, n.1, pp. 177-195.

TAVARES, Luís Henrique Dias (1975). História da Sedição intentada na Bahia em 1798 (A Conspiração dos Alfaiates). São Paulo/Brasília: Pioneira/INL. . (2001). História da Bahia. São Paulo: Editora da Unesp.

VALIM, Patrícia (2007). Da Sedição dos Mulatos à Conjuração Baiana de 1798: a construção de uma memória histórica. Dissertação de Mestrado, DH/FFLCH/USP.

. (2018). Corporação dos enteados: tensão, contestação e negociação política na Conjuração Baiana de 1798. EDUFBA.

(2019). Conjuração Baiana de 1798 e República Bahinense. In: SCHWARCZ, Lilia M. e STARLING, Heloísa M. Dicionário da República. São Paulo: Companhia das Letras, pp. 53-59.

VARNHAGEN, Francisco Adolfo (1981). História geral do Brasil antes de sua separação e independência de Portugal. Belo Horizonte/São Paulo: Itatiaia/Edusp, 10 edição integral.

Artigo recebido em 30 de abril de 2020

Aprovado em 20 de junho de 2020

DOI: $10.12957 /$ intellectus.2020.52500 